\title{
Atrial Arrythmia in Atrial Septal Defect Patient: A Case Report and Review of Literature
}

\author{
Indah Paranita*, Lucia Kris Dinarti, Bambang Irawan
}

\author{
Department of Cardiology and Vascular Medicine, Faculty of Medicine, Public Health and Nursing Universitas Gadjah \\ Mada, Yogyakarta, Indonesia \\ ${ }^{*}$ Corresponding author : \\ Indah Paranita, MD, - email: dr.alfarah@gmail.com \\ Department of Cardiology and Vascular Medicine, Faculty of Medicine, Public Health and Nursing Universitas Gadjah \\ Mada, Yogyakarta, Indonesia \\ Jalan Farmako no1 Sekip Utara, Yogyakarta 55281
}

Manuscript submitted: April 8, 2018; Revised and accepted: August 18, 2018

\begin{abstract}
Atrial fibrillation (AF) and atrial flutter are the most common cardiac arrhythmias associated with atrial septal defects (ASD) in adult patients. The incidence could be as high as $52 \%$ in patients ages 60 years or more.Patient with congenital heart disease who developed atrial arrhythmias had a $>50 \%$ increased stroke risk. Nevertheless, studies regarding the pathophysiological mechanism underlying the high incidence of atrial fibrillation in adult patients with ASD remain relatively few. We reported a female 46 years referred to Sardjito hospital with chest discomfort and palpitation. ECG showed atrial flutter, 90 beat per minute, incomplete RBBB, RAD and RVH. Transthoracal echocardiography shown ASD left to right shunt with diameter $1.2-1.8 \mathrm{~cm}, \mathrm{LA}, \mathrm{RA}$ and RV dilatation, with normal systolic function. From right heart catetherization, the result is ASD High Flow Low Resistance, with pulmonary hypertension (mPAP $44 \mathrm{mmHg}$ ). The consequences of left to right shunt across an ASD is RV volume overload and pulmonary overcirculation. Atrial arrhytmia are a common result of long standing right side heart volume and pressure overload. The idea of combining ASD closure and arrhythmia intervention is another approach to consider.
\end{abstract}

Keywords : atrial fibrillation ; atrial septal defect; atrial arrytmia.

\section{INTISARI}

Aritmia atrial yang paling sering terjadi pada pasien defek septum atrium (DSA) adalah atrial fibrilasi dan atrial flutter. Insidensinya akan meningkat lebih dari $52 \%$ pada pasien dengan usia lebih dari 60 tahun keatas. ${ }^{11}$ Pasien dengan penyakit jantung kongenital yang mengalami aritmia atrial akan memiliki resiko kejadian stroke $>50 \%$. Namun, penelitian mengenai mekanisme patofisiologi yang mendasari tingginya kejadian atrial fibrilasi pada pasien DSA dewasa dengan ASD masih sangat sedikit. Kami laporkan seorang wanita 46 tahun yang dirujuk ke RS Sardjito dengan keluhan dada tidak nyaman dan berdebar. EKG menunjukkan gambaran atrial flutter, 90 kali per menit, RBBB inkomplit, RAD (right axis deviation) and RVH (right ventrikel hypertrophy). Ekokardiografimenunjukkan hasil ASD left to right shunt dengan diameter $1.2-1.8 \mathrm{~cm}$, dilatasi LA, RA and RV dengan fungsi sistolik normal. Hasil penyadapan jantung kanan menunjukkan ASD High Flow Low Resistance, dengan hipertensi pulmonal (mPAP $44 \mathrm{mmHg}$ ). Efek darialiran left to right shunt yang melewati DSA adalah overload volume di ventrikel kanan dan over sirkulasi pulmonal. Aritmia atrial adalah hasil yang didapatkan dari proses overload volume dan tekanan yang lama dari jantung kanan.Ide untuk mengkombinasikan penutupan DSA dengan intervensi aritmia adalah suatu pendekatan yang harus dipertimbangkan. 


\section{INTRODUCTION}

Atrial fibrillation (AF) and atrial flutter are the most common cardiac arrhythmias associated with atrial septal defects (ASD) in adult patients. The incidence could be as high as $52 \%$ in patients ages 60 years or more. Patient with congenital heart disease who developed atrial arrhythmias had a >50\% increased stroke risk. Atrial and ventricular geometrical remodelling secondary to the intracardiac shunt promotes evolution of the electrical substrate, predisposing the patient to atrial fibrillation and other arrhythmias. Nevertheless, studies regarding the pathophysiological mechanism underlying the high incidence of atrial fibrillation in adult patients with ASD remain relatively few. Closure of an ASD reduces the immediate and long-term prevalence of atrial arrhythmias, but the evidence suggests that patients remain at an increased long-term risk in comparison with the normal population.

\section{CASE PRESENTATION}

A female 46 years old referred to Sardjito hospital with chest discomfort and palpitation. Since 2 years before admission the patient often complained chest discomfort and palpitation. Then, the patient check to the primary health care, but the complaints didn't reduce. After 1 years there was no improvement, the patient was referred to cardiologist in Kebumen district hospital. Patient is performed physical examination, electrocardiography (ECG), chest $x$-ray and echocardiography. From all of the examination, the cardiologist concludes that there is atrial septal defect and patient is referred to Cardiology Department of Dr. Sardjito General Hospital for further investigation.

Physical examination reveales holosystolic murmur $3 / 6$ in lower sternal border and wide fixed split S2 sound. An ECG revealed atrial flutter, incomplete right bundle branch block (RBBB), right axis deviation (RAD) and right ventricle hypertrophy (RVH) (figure 1).

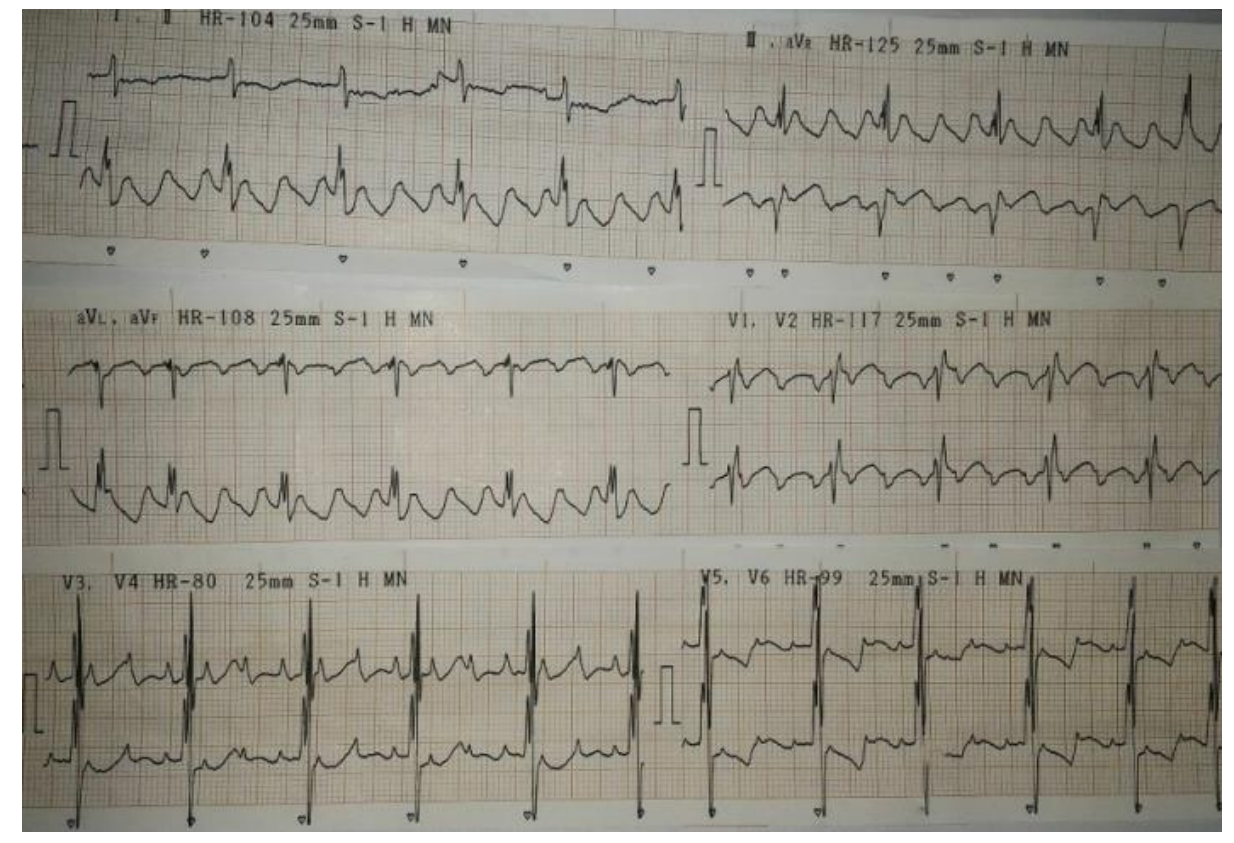

Figure 1. An ECG showed atrial flutter, 90 x/minutes, incomplete RBBB, RAD, and RVH 


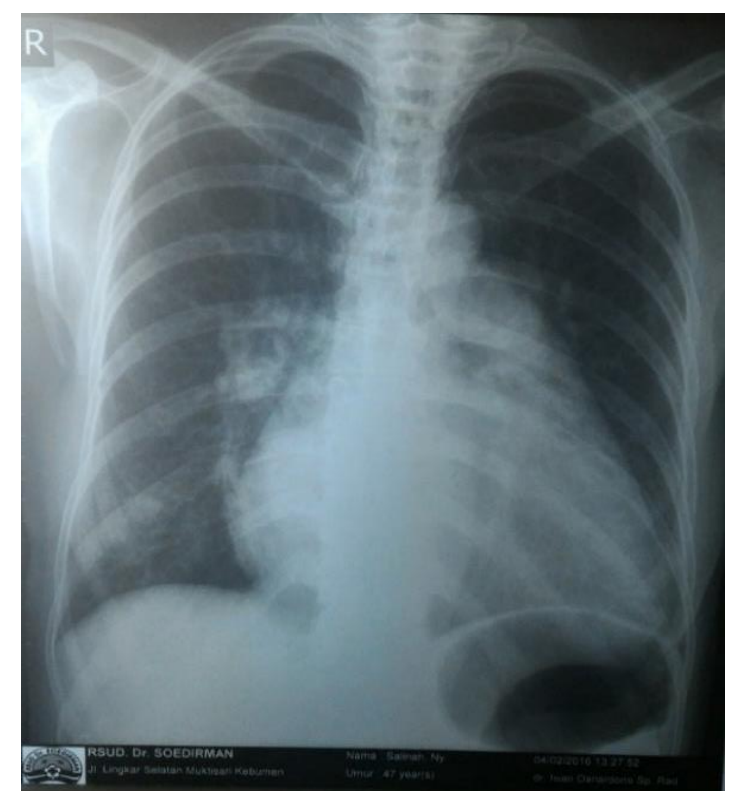

Figure 2. Chest $\mathrm{X}$-ray patient with atrial septal defect

Chest X-ray shows cardiomegaly, $\mathrm{RVH}$, dilatation of left atrium and left ventricle, with prominent pulmonal artery. It indicates the present of pulmonary hypertension. Figure 2 is chest X-ray from the patient.

$$
\begin{gathered}
\text { Laboratory examination is within } \\
\text { normal limit. Transthoracal }
\end{gathered}
$$
echocardiography (TTE) shows an ASD with left to right shunt, ASD diameter is 1.2 $-1.8 \mathrm{~cm}$, left atrial, right atrial and right ventricle dilatation with normal systolic function, left ventricle ejection fraction (LVEF) is $58 \%$. Intraventricular septal paradoks ( LV- D shaped) is observed, sistolic function of RV is decreased (TAPSE $11 \mathrm{~mm}$ ), moderate tricuspid regurgitation, moderate pulmonnary hypertension, mild mitral regurgitation, and mild pulmonary regurgitation. The result from right heart catetherization $(\mathrm{RHC})$ is ASD with high flow low resistance and pulmonary hypertension (mPAP $44 \mathrm{mmHg}$ ).

Patient is diagnosed as ASD secundum with left to right shunt, high flow low resistance, moderate pulmonary hypertension NYHA functional class II and atrial flutter. The patient is treated with oral sildenafil $20 \mathrm{mg}$ t.i.d, digoxin $0.125 \mathrm{mg}$ q.i.d and warfarin $2 \mathrm{mg}$ q.i.d.

\section{DISCUSSION}

Atrial septal defect (ASD) associated with atrial fibrillation (AF) in $10-$
$15 \%$ of patients in older surveys. ${ }^{5}$ The link between AF and ASD is fairly complex and entails modifications in electrophysiologic, contractile and structural properties, at the cellular and tissue level, of both atria, mainly due to chronic atrial stretch and dilation. ${ }^{1}$ This association has important clinical implications for the antithrombotic management of patients with previous stroke or transient ischaemic attack (TIA) and an atrial septal defect. ${ }^{5}$

Atrial flutter and fibrillation are relatively common in ASD and their incidence increases steeply with age. The proneness to these arrhythmias is demonstrated by their common occurrence in patients undergoing surgical repair of the defect, in which postoperative, reversible atrial arrhythmias occur in the majority of patients older than 35 years of age. ${ }^{6}$ The prevalence atrial arrhythmias in ASD is < $2 \%$ in ages around 20 years old, $10-15 \%$ in patients ages 40 years old and $20-40 \%$ in patients ages 60 years old (measured preclosure). ${ }^{4}$

The estimated incidence of atrial arrhythmia is approximately $10 \%$ under the age of 40 years in unoperated adults, rising to at least $20 \%$ with increased age, pulmonary arterial pressure and systemic hypertension. ${ }^{4}$ To reduce the morbidity associated with atrial flutter and fibrillation, the timely closure of atrial septal defects is warranted. ${ }^{9} \quad$ Additional studies have suggested that the incidence is increased in 
male patients, those with chronic obstructive pulmonary disease, reduced ejection fraction and hypertension. ${ }^{4}$

The consequences of left to right shunt across an ASD are RV volume overload and pulmonary overcirculation ${ }^{10}$ Atrial arrhytmia are a common result of long standing right side heart volume and pressure overload. Changes in atrial refractoriness, ionic currents and atrial conduction properties (electrical remodeling), along with tissue remodeling due to atrial fibrosis (structural remodeling) generate a favorable substrate for the initiation and domestication of $\mathrm{AF} .{ }^{12}$ Chronic RA stretch because of ASD causes electrical remodeling with modest increases in RA effective refractory period (ERP), conduction delay at the crista terminalis, and sinus node dysfunction. Conduction delay at the crista terminalis persists beyond ASD closure and may contribute to the long-term atrial arrhythmia substrate in this condition. ${ }^{12}$

On the other hand, as a result of chronic dilatation of the RV, the LV in ASD patients is subject to paradoxical septal motion, diminished impaired diastolic filling, diminished preload, and failed cardiac output recruitment in exercise.Nevertheless, the structural remodeling in the left atrium under chronic right atrial and right ventricular dilatation in ASD patients remains largely unknown. ${ }^{11}$ An ASD is associated with chronic LA stretch, which results in remodeling characterized by LA enlargement, loss of myocardium, and electrical scar that results in widespread conduction abnormalities but with no change or an increase in ERP. These abnormalities were associated with a greater propensity for sustained AF. ${ }^{14}$

The prevalence of $A F$ is almost similar in surgical and non surgical patient. It relates to advanced age, left atrial enlargement and grade of severity of mitral and tricuspid regurgitation. Gender, anatomic type, defect size, Qp:Qs, pulmonary artery pressure, right ventricular dimension, left ventricular systolic function or previous surgical repair are not significantly related to late AF. Age $>25$ years at the time of surgical closure of ASD was the only predictor for AF in surgically treated patients independent of age at the time of study. ${ }^{13}$ Data from the Framingham study indicate that its prevalence double with each advancing decade of age, from
$0,5 \%$ at ages $50-59 \%$ years to almost $9 \%$ at ages $80-89 \%$ years. Oliver et al. (2002) shows a significant increase in the prevalence of $\mathrm{AF}$ with each increased decade of age in ASD. It shows the rate of $\mathrm{AF}$ is $<2 \%$ in patient $<30$ years, $15 \%$ in patients in their 50 years, and $>60 \%$ in patients in their 70 years. ${ }^{13}$

Adult patients with an ASD and atrial tachyarrhythmias get benefit from defect closure. Closure of the defect may lead to regression of atrial flutter, whereas in older patients ( $>25$ years) with AF, restoration of normal hemodynamics alone may not be sufficient. ${ }^{2}$ Device closure of ASD leads to improvement of both RV and LV function as well as reduction in LA volume. These hemodynamic improvements provide insights into the symptomatic benefits gained in closure of ASD using the transcatheter approach. Whether a reduction in LA volume predicts a reduction in probability of later arrhythmias in a given patient remains to be determined. ${ }^{15}$

The management of patients with congenital heart disease and $\mathrm{AF}$ is similar to the management of AF encountered in other forms of heart disease. Acute management involves anticoagulation and rate control as needed, followed by consideration of cardioversion to restore sinus rhythm. ${ }^{8}$ Nonpharmacological therapies for rhythm management include catheter or surgical ablation. ${ }^{7}$ Successful control of AF has been reported after combined RA and LA Maze procedures, which may be considered in patients requiring cardiac surgery to correct hemodynamic issues. There are also very limited report of radiofrequency catether ablation prior to device closure of ASD at a separate procedur. In Santangeli study ${ }^{16}$ state that radiofrequency catheter ablation of $A F$ is feasible, safe, and effective in patients with ASD closure devices. Transseptal access can be obtained in portions of the native septum in the majority of cases. Direct transseptal puncture of the device is feasible and safe but requires longer time for each transseptal access.

\section{CONCLUSION}

An ASD are frequently associated with atrial arrhythmias and their incidence increase steeply with age. Atrial Arrythmias in ASD patients is mainly the byproduct of 
RA and LA dilatation. Changes in atrial refractoriness, ionic currents and atrial conduction properties (electrical remodeling), along with tissue remodeling due to atrial fibrosis (structural remodeling) generate a favorable substrate for the initiation and domestication of atrial tachyarrhythmias. For the patient was recommended surgical closure to improve exercise capacity, to prevents right to left shunt, and to eliminates heart failure.

\section{REFERENCES}

1. Blake G.E., Lakkireddy D. 2008. Atrial septal defect and atrial fibrillation: the known and unknown. J Atr Fibrillation, 1:45.

2. Berger F., Vogel M., Kramer A. (1999). Incidence of atrial flutter/ fibrillation in adults with atrial septal defect before and after surgery. Ann Thorac Surg, 68:75-78.

3. Bernstein D. 2007. 'Congenital heart disease'. In: Kliegman RM, Behrman RE, Jenson HB, Stanton BF, Nelson textbook of pediatrics, Edisi ke-18, Saunders Elsevier, Philadelphia,pp 1878-81.

4. Chubb H., Whitaker J., William S.E., Head C.E., Chung N.A.Y., Wright M.J., et al. 2014. Patophysiology and management of arrhytmias associated with atrial septal defect and patent foramen ovale. Arrhythm Electrophysiol Rev, 3:168-172.

5. Camm A.J., Kirchhof P., Lip G.Y.H., Schotten U., Savelieva I., Ernst S., et al. 2010, Guidelines for the management of atrial fibrillation: the Task Force for the Management of Atrial Fibrillation of the European Society of Cardiology (ESC). Eur Heart J, 31:2369-2429.

6. Craig R.J., Selzer A. 1968. Natural history and prognosis of atrial septal defect. Circulation, 37:805-815.

7. Crandall M.A., Daoud E.G., Daniels C.J., Kalbflleisch S.J. 2012. Percutaneous radiofrequency catheter ablation for atrial fibrillation prior to atrial septal defect closure. J
Cardiovasc electrophysiol, 23:102104.

8. Darby A.E., DiMarco J.P. 2012. Management of atrial fibrillation in patients with structural heart disease. Circulation, 125:945-957.

9. Gatzoulis M.A., Freeman M.A., Siu S.M., Webb G.D., Harris L. 1999. Atrial arrhytmia after surgical closure of atrial septal defect in adults. N Engl J Med, 340:839-846.

10. Gelernter-Yaniv L., Lorber A. 2007. The familial form of atrial septal defect. Acta Paediatr, 96: 726-730.

11. Lin J.L. 2009. Atrial fibrillation in atrial septal defect : A problem of right atrium or left atrium?, Heart Rhytm, 6:1007-1008.

12. Morton J.B., Sanders P., Vohra J.K., Sparks P.B., Morgan J.G., Spence S.J., et al. 2003. Effect of chronic right atrial stretch on atrial electrical remodeling in patients with an atrial septal defect. Circulation, 107:17751782.

13. Oliver J.M., Gallego P., Gonzalez A., Benito F., Mesa J.M., Sobrino J.A., 2002, Predisposing condition for atrial fibrillation in atrial septal defect with and without operative closure. Am J Cardiol, 89:39-43.

14. Roberts-Thomson K.C., John B., Worthley S.G., Brooks A.G., Stiles M.K., Lau D.H., et al. 2009. Left atrial remodelling in patient with atrial septal defect. Heart Rhytm, 6:10001006.

15. Salehian O., Horlick E., Schwerzmann M., Haberer K., McLaughlin P., Siu S.C., et al. 2005. Improvements in cardiac form and function after transcatheter closure of secundum atrial septal defects. J Am Coll Cardiol, 45:499-504.

16. Santangeli P., Di Biase L., Burkhardt J.D., Horton R., Sanchez J., Bailey S., et al. 2011. Transeptal acces and atrial fibrillation ablation guided by intracardiac echocardiography in patient with atrial septal closure devices. Heart Rhythm, 8:1669-1675. 